Print ISSN: 2288-4637 / Online ISSN 2288-4645

doi:10.13106/jafeb.2020.vol7.no5.051

\title{
Audit Expectation Gap: Empirical Evidence from Vietnam*
}

\author{
Hieu Thanh NGUYEN ${ }^{1}$, Anh Huu NGUYEN²
}

Received: March 13, 2020 Revised: March 21, 2020 Accepted: April 03, 2020

\begin{abstract}
The paper examines the characteristics and causes of the expectation gap of audit and assurance services. The paper has conducted three surveys with three target groups. In the first survey, participants are auditors, users of audit reports are subject in the second survey and in the third survey, and students major in auditing are selected. The content of the survey aims to find out the differences in perception of the survey participants on two issues: (i) responsibilities of auditors for detection frauds, errors, protection of the enterprise's assets and financial scandals, and (ii) the role of audit and auditors in making investment decisions and investor's belief. The research carried out survey from March to September 2019 with 165 responds. The collected data was processed by statistical software SPSS, version 23, and Mann-Whitney $\mathrm{U}$ test was used to analyze the results of the audit expectation gap between the auditor group and the users of audit report group and between the student group and users of audit report group. The results showed that there exists an expectation gap in the responsibility of auditors for detection of all frauds, errors and protection enterprise's assets. Recommendations include strengthening audit standards, penalizing bad practices and ensuring auditor's independence.
\end{abstract}

Keywords: Audit, Expectation, Gap, Manager, Responsibility

JEL Classification Code: M10, M40, M42

\section{Introduction}

Along with the development of the market economy, the household business model consisting of only a few members of in the family has been gradually replaced with a corporation model, with a large numbers of outside family members. When businesses grow to a certain extent, business relationships also extend constantly. At that time,

\footnotetext{
* This research is funded by the National Economics University (NEU), Hanoi, Vietnam. The authors thank anonymous referees for their contributions and the NEU for funding this research.

${ }^{1}$ First Author and Corresponding Author. Lecturer, School of Accounting and Auditing, The National Economics University, Vietnam [Postal Address: 207 Giai Phong Road, Dong Tam Ward, Hai Ba Trung District, Hanoi, 116000, Vietnam]

Email: hieu39ktqd@gmail.com

${ }^{2}$ Dean, School of Accounting and Auditing, National Economics University, Vietnam. Email: anhnh@neu.edu.vn

(c) Copyright: The Author(s)

This is an Open Access article distributed under the terms of the Creative Commons Attribution Non-Commercial License (http://Creativecommons.org/licenses/by-nc/4.0/) which permits unrestricted noncommercial use, distribution, and reproduction in any medium, provided the original work is properly cited.
}

the owner has not been the manager of the enterprise and vice versa, so the needs for the report on financial situation and operating performance of enterprises are absolute necessary. According to the theory of information asymmetry and agency theory, there is always a conflict of interest between shareholders and managers. Thus, it is still possible to deal with earning management when the managers use judgment in financial reporting to alter financial reports to mislead some stakeholders (Nguyen \& Duong, 2020). Therefore, in order to confirm that such reports are fair, reasonable and without material misstatement, the users of financial statements believe that an independent party should check the reports. Therefore, the audit profession has been established and it developed. The main function of audit is to provide assurance services to help shareholders, investors and other entities with interests related to the enterprises to be assured of the truthfulness and reasonableness of the financial reports.

Gradually, the audit and assurance services have been highly appreciated by companies, and auditors take an important instrument of corporate governance to ensure the transparency and accountability of the firm to the 
stakeholders (Rahman, Meah, \& Chaudhory, 2019). The users of the audit report have more expectation about the auditor's ability as well as auditor's performance. In fact, auditors are not able to guarantee all matters of enterprises because those problems do not depend only on the auditor's performance, but also on the nature of the business. There are different points of view between the opinions of the auditors and the users of an audit report, called audit expectation gap.

As regards theory, the study of the audit expectation gap began in 1974. The concept of audit expectation gap was first introduced by Liggio (1974). The author described this gap as the difference between auditors and users of audit report about the auditor's performance. Subsequently, there were numerous papers contributing on this issue such as: Baron, Douglas, Johnson, Searfoss and Smith (1977), Epstein and Geiger (1994), and Humphrey, Moizer and Turley (1993). It has been proven that studies in different contexts give inconsistent results on the characteristics of audit expectation gap and the level of audit expectation gap. Baron, Douglas, Johnson, Searfoss, and Smith (1977) argued that there was an expectation gap regarding the auditor's responsibility to detect and report fraud and non-legal conduct while Best, Buckby, and Tan (2001) insisted on an expectation gap in the auditor's responsibility for the effectiveness of the internal control system of the audited firm. In contrast, Fadzly and Ahmad (2004) indicated that there were no significant differences between the auditors and users except in their performance monitoring.

In term of practice, for any profession, the belief of the public and society is very important because it builds the reputation and sustainability of the job. In particular, the auditing profession is more important because it is directly related to the interests, money and property of people. Financial scandals of WorldCom, the second largest telecommunications company in the United States or Enron Energy Group, the largest energy company in the United States, leading to the collapse of Arthur Andersen, the world's leading audit firm, is a living testament to the failure of the US audit industry. The consequences of these events have caused many losses to investors, and they have raised many doubts about the quality and truthfulness of the audit report (Tran, Khairi, \& Laili, 2019). The society expected to receive accurate results from the auditors' reports, but with the above situation, the users of financial statements were disappointed and lost confidence in the quality of the audit exercise. Therefore, there exists an audit expectation gap of society with the audit results of auditors and auditing firms. In the context of Vietnam, empirical research showed that three factors - auditee size, Big 4 audit firms, and auditee complexity measured by number of subsidiaries, branches, associates, affiliates and joint ventures - have a statistically significant positive effect on the audit fee for companies (Nguyen \& Tran, 2017).
In fact, there still exist many different perspectives on the audit profession, especially the responsibilities and obligations of auditors. In order to improve the reliability of the audit report, the auditor always aims to achieve the lowest audit risk, that is, to detect as many errors and frauds as possible. On the side of investors, using the financial statements of enterprises to make decisions, always hope to get a published financial report with the least errors (Nguyen, Pham, \& Nguyen, 2020). As such, both auditors and users of financial statements have the same desire to minimize errors in financial statements. However, the expectations of the investors and the results achieved by the actual audit are difficult to identify because of the inherent nature of fraud on the financial statements.

For the above reasons, the study of audit expectation gap is significant in both theory and practice. Especially, this research has been conducted in developed countries, but has not been systematically carried out in a transitional and developing economy like Vietnam, in recent years. This paper has an important social significance; it shows the practical requirements for the audit profession as well as the perceived views of users of financial statements about obligations and responsibilities of the auditors in Vietnam. Investors need to know how the auditor is responsible for preventing and detecting fraud so they know how much they can trust their financial statements and what information they need to consider before investing. On the other hand, the auditor needs to identify the expectations of those who are interested and use the financial statements to perform and communicate properly their roles and responsibilities.

The main goal of this paper is to find evidence that an audit expectation gap exists in Vietnam and, then, the authors will propose some ideas to close the gap. From the research objectives, the authors raise two research questions:

Research question 1: Is there a difference in the perception of auditors and users of audit report in Vietnam as regards the auditor's responsibilities and the audit role?

Research question 2: If there is an audit expectation gap, what is the auditor's responsibility and what role of audit is the cause for this gap?

The remainder of the paper is structured as follows: Section 2 reviews the Literature; Section 3 presents Research Hypotheses; Section 4 covers the Research Methodology; Results and Discussion of audit expectation gap in Vietnam are presented in Section 5. Finally, the recommendations are offered in Section 6.

\section{Theory and Literature Review}

\subsection{Basic Theory}

Theories related to the expectation gap, namely, Role Theory, Inspired Confidence Theory and Agency Theory, are introduced here: 
Role Theory: The role is a behavioral system that relates to a specific position in the social system. A role is defined as a social position, behavior related to a social position, or typical behavior. Each social role is a set of rights, obligations, expectations, norms, and behaviors that a person faces and fulfills. There are many different interpretations of the role. Some researchers think that role relates to expectations about an individual's behavior in given situation. When each person holds social positions, his or her behavior is determined primarily by the expectations associated with that position, rather than individual characteristics. In the area of auditing, the auditor has a reasonable role in ensuring that the financial statements are materially flawed due to fraud or not are governed by expectations for that role. However, how much their behavior can meet society's expectations is still a matter of debate and therefore the concept of audit expectation gap exists.

Inspired Confidence Theory: Theory of Inspire argued that the auditor derives his general function in society from the need for an expert and independent opinion based on that examination. The function is rooted in the confidence that society places on the effectiveness of the audit and in the opinion of the accountant. This confidence is, therefore, a condition for the existence of that function; if the confidence is betrayed, the function, too, is destroyed, since it becomes useless. He went on to argue that, there were two circumstances in which the confidence could be betrayed. It could be betrayed if the expectation of society is exaggerated, that is, it exceeds what the auditor is capable performing. Conversely, it can be betrayed if the auditor under-performs. He recognized that society's demands are not static. They are dynamic and influenced by changing perceptions and changes in the environment. The central area of theory is related to the social responsibility of the independent auditor and possible mechanisms for ensuring that audits meet society's need.

Agency Theory: Agency theory analyses the relationship between two parties: shareholders and managers. Because of information asymmetry, company managers tend to take advantage of corporate resources to serve their own interest rather than serving shareholders' benefits (Tran, 2019). The agent (that is, managers) undertakes to perform certain duties for the principal (that is, investors) and the principal undertakes to reward the agent (Jensen \& Meckling, 1976). Audit serves a fundamental purpose in promoting confidence and reinforcing trust in financial information. Agency theory is a useful economic theory of accountability that helps to explain the development of the audit. Agency theory posits that agents have more information than principals and that this information asymmetry adversely affects the principals' ability to monitor whether their interests are being properly served by the agents.

\subsection{Literature Review}

The topic of audit expectation gap emerged in the 1970s by Liggio (1974). Over the past 40 years, this topic has been of great interest in many countries. According to Liggio (1974), the audit expectation gap is the difference between the level of work performed by the auditors and the expectation of users on that work. According to Guy and Sullivan (1988), there is a difference between what the society and users of audit report believe the auditor is responsible for and what the auditor thinks they are responsible for. Monroe and Woodliff (1993) state that the audit expectation gap is the difference of opinion between the auditor and the public regarding the duties and responsibilities of auditors. Studies on the nature of the audit expectation gap have been conducted in different countries for many decades. The basis for the study lies in Lee (1970) on what the auditor is expected to perform. Since that time, most studies confirm that the auditor's opinion and public opinion on the auditor's role and responsibilities can be obtained through the questionnaire survey.

In the United States, Baron, Douglas, Johnson, Searfoss, and Smith (1977) examined the level of responsibility for detecting material misstatements, frauds and the illegal acts of auditors. They try to determine if there are differences in perceptions regarding responsibilities between auditors and users of audit report. They found that auditors and users of audit report had different views on detecting and presenting irregularities and illegal behaviors. Particularly, users of audit report require the auditor to be more responsible for the detection and reporting of fraud and non-compliance activities than what the auditor believes he / she must do.

Low (1980) investigated the extent of detection and responsibility for disclosing errors, frauds and other illegal behaviors as perceived by auditors and users of audit report group in Australia. As a result, both groups have completely different perceptions. Low, Foo, and Koh (1988) studied the extent of the expectation gap between auditors and financial analysts on audit objectives in Singapore. The results indicate that the basic objective of the audit is to express opinion of auditors on financial statements of audited firm. However, financial analysts believe the audit is a guarantee of the accuracy of an entity's financial statements. Furthermore, the views of financial analysts on the auditor's responsibility to prevent and detect material misstatement are more rigorous than what auditors do.

In another survey, Humphrey, Moizer, and Turley (1993) examined the audit expectation gap in UK by examining the perceptions of individuals of audit expectations issue through the use of a questionnaire survey comprising a series of mini cases. The results of survey revealed a significant difference between auditors and the users of audit report. The results confirmed the existence of an audit expectation gap, specifically due to the nature of the audit function and the 
perceived performance of auditors. The critical components of the expectation gap were found including auditors' fraud detection role, the extent of auditors' responsibilities to third parties, the nature of balance sheet valuations, the continuing threats to auditors' independence, and auditors' ability to cope with the risk and uncertainty.

Epstein and Geiger (1995) studied the audit expectation gap between investors and auditors, and concluded that (i) investors expected more about the level of assurance that the auditor could do regarding detecting fraud and errors; (ii) the investor lacks understanding of the auditor's ability to detect errors and fraud; and (iii) investors do not understand the difficulty of auditors in detecting material misstatements due to frauds and errors when auditing financial statements. Based on these findings, Epstein and Geiger (1995) suggest that the auditor needs to inform the public of the difficulties in fraud detection and the auditor needs to increase both the quality and the number of auditing services to provide investors with a higher level of assurance.

Best, Buckby, and Tan (2001) studied the audit expectation gap in Singapore. This study provides more detail on the nature and extent of audit expectations gap. Sharing research findings with Epstein and Geiger (1995), Best, Buckby, and Tan (2001) also confirm that there are significant differences in the opinion of the auditor and the user of the financial statements regarding the auditor's responsibility to detect all frauds and errors. In addition, investors believe that the auditor is responsible for the effectiveness of internal control system at the client's company. McEnroe and Martens (2001) conducted a survey in United States to obtain perceptions of auditors and investors on the extent to which an expectation gap did exist in various dimensions of the auditing function. The findings of the research showed that investors did not concur with the panel on the Public Oversight Board (POB) and the public was not the auditor's true client. The appropriate action to reduce these expectations might be reduced through education.

Fadzly and Ahmad (2004) examined the perceptions on 'what the auditors were doing' by comparing theirs and the users' perceptions in Malaysia. The study addressed the expectation gap through the auditors' responsibilities, reliability of audit, and usefulness of audited financial statements. The empirical results indicated that there were no significant differences in beliefs between the auditors and users except in the financial statements, which gave a true and fair view. Three statements on usefulness pertained to the use of the audited financial statements in decision making, performance monitoring and assessing whether the entity was well managed. The empirical result indicated that there were no significant differences between the auditors and users except in their performance monitoring.
Lin and Chen (2004) conducted an empirical study on the audit expectation gap in China. The study investigated the rise of the expectation gap and related the auditing issues under business and auditing environment in the country. There was an expectation gap with respect to the objectives of auditing, auditors' obligation to detect and report frauds or irregularities, responsibility of auditors to the third party, and the impact of governmental sponsorship on the credibility of the audit services. The auditors and audit beneficiaries were dissatisfied with the present situation of auditor's independence in China. They concluded that much must be done to improve the public accounting practices in China to bridge the expectation gap. A survey conducted by Salehi and Azary (2008) regarding fraud detection in Iran between bankers and auditors. The result of study revealed that there was a gap between two parties on auditors' responsibility on fraud detection. Bankers believed that auditors should detect all fraud. However, auditors did not agree with such idea.

Chu and Ki (2019) examines whether auditors restrain the analysts' opportunistic behavior as reviewing the companies' interim reports. They use data from Korea, where it is mandatory to disclose auditor's review hours. This study sheds light on discussions on expanding and strengthening auditors' review of interim reports. This study shows that auditors' efforts in the review of interim reports plays a significant role in curbing the analysts' optimism early in the year. From the review of the study, the authors found that new studies were concentrated in developed countries such as the US (Baron, Douglas, Johnson, Searfoss, \& Smith, 1977; McEnroe \& Martens, 2001), in Australia (Low, 1980), in the UK (Vinten, 2005), but research in developing countries and transitional economies like Vietnam is still very few. In addition, the studies do not cover other aspects of the auditor's responsibility (i.e. financial scandals, asset losses) and the role of the auditor in making investor decisions and investor belief.

\section{Research Hypotheses}

From the research literature, this study proposes eight research hypotheses:

Hypothesis 1: There is an audit expectation gap between auditors and users of audit report on the responsibility of auditors to detect all frauds and errors in enterprises in Vietnam.

Hypothesis 2: There is an audit expectation gap between auditors and users of audit report on the responsibilities of auditors in protecting the assets of audited enterprises in Vietnam.

Hypothesis 3: There is an audit expectation gap between auditors and users of audit report on auditors' responsibility for financial scandals and the loss of enterprise's assets in Vietnam. 
Hypothesis 4: There is an audit expectation gap between users of audit report and auditors on the role of auditors in making investment decision in Vietnam.

Hypothesis 5: There is an audit expectation gap between users of audit report and auditors on the role of auditors in providing trust to investors in Vietnam.

Hypothesis 6: There is an audit expectation gap between users of audit report and auditing major students on auditors' responsibility to detect all frauds and errors of the business in Vietnam.

Hypothesis 7: There is an audit expectation gap between users of audit report and auditing major students on auditors' responsibility to financial scandals and loss of assets of users in Vietnam.

Hypothesis 8: There is an audit expectation gap between users of audit report and auditing major students on the role of financial audit and auditors in providing trust to investors in Vietnam.

\section{Research Methodology}

\subsection{Data Collection}

The research method used in the paper is the qualitative combine with quantitative research method. Specifically, the authors designed questionnaires based on those in previous studies, with some small modifications for the questionnaire to be suitable in the Vietnamese context (Pham \& Hoang, 2019). Then, the authors conducted a pilot survey on a small group and, on that basis, adjusted the questionnaires accordingly. Next, adjusted questionnaires were sent to students of universities and auditors working at Big 4 auditing firms, bank staff of commercial banks in Hanoi. Besides, the authors have delivered 180 survey questionnaires and collected 165 responses, corresponding to $91.67 \%$ response. In order to determine the minimum sample size for the study, the authors applied the required exploratory factor analysis: $\mathrm{N}=5 * \mathrm{~m}$ (m: number of questions). With 14 questions in the survey questionnaire, a minimum of 70 samples to ensure the reliability of the study results. The sample selected is 165 greater than the minimum number of samples required (70), so the size of samples meets the requirements, the sample results can be used to infer the population.

In addition, the Likert-scale survey question sheet was designed with 14 questions based on the research of Yasemin and Sedat (2015). Each question has five level of agreement: totally disagree, disagree, neutral, agree and completely agree, with the numbers from 1 to 5 . The survey questionnaire consists of two parts:

Part A: Information about the objective of the survey and general information on survey participants (i.e. occupations of responds, numbers of working years, audit knowledge)
Part B: Understanding of the responsibility of the auditor and the role of the financial audit and auditors in making investment decisions, and to the belief of investors.

The questions that respondent leave blank or for which they did not give the right answer were eliminated and not be used for analyzing this research results.

\subsection{Analysis Methodology}

The information and data collected by the authors are used to perform the Mann-Whitney U test as followed:

Mann test - Whitney U makes the following assumption:

$\mathbf{H}_{0}$ : There is no difference between the two groups

$\mathbf{H}_{1}$ : There are differences between the two groups

With significance level of $\alpha=5 \%$, if the test result has $\mathrm{P}$-value value greater than 0.05 , it is not enough evidence to reject the $\mathrm{H}_{0}$ assumption. That means there is an audit expectation gap between auditors, auditing major students. Conversely, if the test result has a P-value less than 0.05 , the $\mathrm{H} 0$ assumption in the test is rejected, the $\mathrm{H}_{1}$ assumption is accepted. That means there is no audit expectation gap between auditors, auditing major students and users of audit report.

\section{Results and Discussions}

\subsection{Descriptive Statistics}

Regarding the gender of the surveyed respondents: Out of 165 respondents, 67 were females $(40.6 \%)$ and 98 males (59.4\%). The occupation of the respondents were divided into several categories such as auditors, bank staff, auditing major students and other professions. The results showed that 29 people surveyed are auditors, accounting for $17.6 \%$; there are 57 auditing major students, representing $34.5 \%$ of the respondents. The remaining $47.9 \%$ of survey sample are bank staff and other professions.

In term of the number of years of experience of the respondents: the results of the survey on work experience of the target groups showed that the highest proportion of respondents (80) had an experience of less than one year, equivalent to $48.5 \%$, because the group collected 57 responses from auditing major students who do not have much working experience. With $48.5 \%$ of people with experience of less than one year, they may not be fully aware of the role and responsibilities of auditors in auditing. Meanwhile, the number of people with over five years of experience is 32 , accounting for $19.4 \%$. They have worked for a relatively long term, so they have more opportunity to interact with audit report as well as cases encountered when implementing audit. Therefore, they are more aware of the auditor's roles and auditor's responsibilities. Among 
165 survey respondents, 97 people, accounting for $58.8 \%$ of respondents, have been trained in auditing, show that they may not be in the auditing field, but they still have audit knowledge.

\subsection{Results of Audit Expectation Gap}

\subsubsection{The First Survey's Results}

Firstly, summarizing the opinions of auditors and users of audit report in detecting errors and frauds in the enterprise. With Question No.1 about detecting and reporting all the errors and frauds that exist in the business, more than $60 \%$ of auditors disagree (only $39.06 \%$ agree) that they are responsible for detecting and reporting all the frauds and errors of the companies. Contrary to the opinions of auditors, $60.83 \%$ of users of audit report said that auditors must detect all errors and frauds. As regards Question No.9, 68.64\% of auditors agreed that the managers are responsible for their own mistakes, but $48.31 \%$ of users of audit report said that it is the duty of the managers. This shows that the two groups have different points of view. Results are shown in Table 1.

Performing the Mann-Whitney test showing that all $p$-values are less than 0.05 , there is a difference in the opinion of auditors and users of audit report regarding the detection of all frauds and errors exist in financial statements. Thus, hypothesis $\mathrm{H} 1$ is accepted. The results of this study agree with the results of Epstein and Geiger (1995); Salehi and Azary (2008).
Secondly, summarizing the opinions of auditors and users of audit report on responsibility of auditor for protecting assets of audited firms. With the test results shown in Table 2, the value of Mann-Whitney $\mathrm{U}=718,500$; Wilcoxon $\mathrm{W}=3878,500 ; \mathrm{Z}=-3.073 ; \mathrm{P}>|\mathrm{Z}|=0.002$ and significance level $\alpha=5 \%$. Since $P>|Z|=0.002$ less than 0.05 , according to the rules of the test, $\mathrm{H}_{\mathrm{o}}$ is rejected and accepted $\mathrm{H}_{1}$. That means, between the auditors and the users of audit reports, there are also differences of opinion in property protection responsibilities. $60.83 \%$ of users of audit report expect auditors to be responsible for protecting the assets of businesses, while only $37.26 \%$ of auditors think their responsibility is only to verify and express opinions about the existence of assets. Thus, the hypothesis $\mathrm{H} 2$ is accepted.

Thirdly, summarizing the opinions of auditors and users of audit report on the responsibility of the auditor for corporate financial scandals and loss of the parties using the financial statements after the audit. Through Questions No.4, No.8, No.10, No.11, the survey results in Table 3 showed that both groups agreed that the managers of the enterprise must be responsible for the business scandals and the loss of users of the audit report when making decisions. It is not the responsibility of auditors. Specifically, in Question 10,63.11\% of auditors agree that the managers must be responsible for the scandals causing damage to the company's assets, and $61.31 \%$ of users of audit report go

Table 1: Results of perceptions of auditors and users of audit report on responsibilities of auditors for finding all errors and frauds in financial statements.

\begin{tabular}{|c|c|c|c|c|c|c|}
\hline Question & $\begin{array}{l}\text { Number of } \\
\text { respondents }\end{array}$ & Mean rank & $\begin{array}{c}\text { Mann-Whitney } \\
\text { U }\end{array}$ & Wilcoxon W & Z & $P>|Z|$ \\
\hline \multirow{2}{*}{1} & 29 & 39.06 & \multirow{2}{*}{645.500} & \multirow{2}{*}{1080.500} & \multirow{2}{*}{-3.598} & \multirow{2}{*}{.000} \\
\hline & 79 & 60.83 & & & & \\
\hline \multirow{2}{*}{2} & 29 & 36.41 & \multirow{2}{*}{621.000} & \multirow{2}{*}{1056.000} & \multirow{2}{*}{-3.783} & \multirow{2}{*}{.000} \\
\hline & 79 & 61.14 & & & & \\
\hline \multirow{2}{*}{3} & 29 & 32.84 & \multirow{2}{*}{517.500} & \multirow{2}{*}{952.500} & \multirow{2}{*}{-4.502} & \multirow{2}{*}{.000} \\
\hline & 79 & 62.45 & & & & \\
\hline \multirow{2}{*}{9} & 29 & 68.64 & \multirow{2}{*}{735.500} & \multirow{2}{*}{3895.500} & \multirow{2}{*}{-3.029} & \multirow{2}{*}{.002} \\
\hline & 79 & 48.31 & & & & \\
\hline
\end{tabular}

Table 2: Results of perceptions of auditors and users of audit report on responsibilities of auditors for protecting assets of audited firms.

\begin{tabular}{|c|c|c|c|c|c|c|}
\hline Question & Numbers of people & Mean rank & Mann-Whitney U & Wilcoxon W & $\mathbf{Z}$ & $\mathbf{P}>|\mathbf{Z}|$ \\
\hline \multirow{2}{*}{6} & 29 & 37.26 & 718.500 & 3878.500 & -3.073 & 0.002 \\
\cline { 2 - 6 } & 79 & 60.83 & & & \\
\hline
\end{tabular}


along with this statement. The test results in Table 3 showed $\mathrm{P}>\mid \mathrm{Z}$ greater than 0.05 , meaning that users of audit report and auditors have similarities, no difference in opinion, about the scandals happening at the enterprise and the loss of the users of audit report after audit in decision making. Thus, hypothesis $\mathrm{H} 3$ is not accepted

\subsubsection{The Second Survey's Results}

The authors explored opinions of auditor and users of audit report on the role of audit and auditors. In this section, the group gave answers to 5 questions. Firstly, summarizing the opinions of auditors and users of audit report on role of audit and auditors in making investment decisions.

Table 4 showed that, up to $79.33 \%$ of auditors agree that audited reports affect investment decisions of investors. Bankers and investors also agreed with the above questions with the rate of $64.54 \%$. Thus, there does not exist an audit expectation gap between the information user and the auditor about the role of the auditor and the audit report on the investor's investment decision as shown in Table 4 . The result shows that $\mathrm{P}>|\mathrm{Z}|$ receives values of $0.660 ; 0.318$; 0.179 greater than 0.05 (significant level 5\%). It is further confirmed that the auditor and its partners think that auditing results influence their investment and lending decisions. Therefore, they think that the role of auditors and auditor is very important, helping them to recognize and make better decisions. Therefore, the hypothesis H4 is not accepted. Secondly, summarizing the opinions of auditors and users of audit report on role of audit and auditors in investor's trust.

Through Question No. 14, 82.72\% of auditor said that the audit report is a reliable source of information showing financial status and performance of businesses, and $77.94 \%$ of bank officers and investors agree with this statement. The results in Table 5 show that $\mathrm{P}>|\mathrm{Z}|$ receives the value of 0.398 and 0.32 are both greater than 0.05 , so it can be seen that users of audit reports and auditors have no difference in opinion, and they also think that audit reports contribute to investor confidence. Thus, hypothesis H5 is not accepted. Results about the existence of audit expectation gap between audit report users and auditor about the role of audit and auditor to investor confidence are shown in Table 5 below.

\subsubsection{The Third Survey's Results}

The authors compared the views of auditing-major students and users of audit report on auditor's responsibilities, the role of auditing financial statements and auditor in

Table 3: Results of perceptions of auditors and users of audit report on responsibilities of auditors for corporate financial scandals and loss of the parties using the financial statements after the audit.

\begin{tabular}{|c|c|c|c|c|c|c|}
\hline Question & $\begin{array}{c}\text { Numbers of } \\
\text { people }\end{array}$ & Mean Rank & $\begin{array}{c}\text { Mann-Whitney } \\
\text { U }\end{array}$ & Wilcoxon W & $\mathbf{Z}$ & $P>|Z|$ \\
\hline \multirow{2}{*}{4} & 29 & 63.19 & \multirow{2}{*}{893.500} & \multirow{2}{*}{4053.500} & \multirow{2}{*}{-1.863} & \multirow{2}{*}{0.062} \\
\hline & 79 & 61.31 & & & & \\
\hline \multirow{2}{*}{8} & 29 & 51.10 & \multirow{2}{*}{1047.000} & \multirow{2}{*}{1482.000} & \multirow{2}{*}{-.706} & \multirow{2}{*}{0.480} \\
\hline & 79 & 55.75 & & & & \\
\hline \multirow{2}{*}{10} & 29 & 63.11 & \multirow{2}{*}{962.000} & \multirow{2}{*}{1342.000} & \multirow{2}{*}{-1.153} & \multirow{2}{*}{0.133} \\
\hline & 79 & 61.31 & & & & \\
\hline \multirow{2}{*}{11} & 29 & 28.86 & \multirow{2}{*}{982.000} & \multirow{2}{*}{1417.000} & \multirow{2}{*}{-1.178} & \multirow{2}{*}{0.239} \\
\hline & 79 & 26.57 & & & & \\
\hline
\end{tabular}

Table 4: Perceptions of auditors and users of audit report on role of audit and auditors in making investment decision

\begin{tabular}{|c|c|c|c|c|c|c|}
\hline Question & $\begin{array}{c}\text { Numbers of } \\
\text { people }\end{array}$ & Mean Rank & $\begin{array}{c}\text { Mann-Whitney } \\
\text { U }\end{array}$ & Wilcoxon W & $\mathbf{Z}$ & $P>|Z|$ \\
\hline \multirow{2}{*}{12} & 29 & 56.53 & \multirow{2}{*}{1086.500} & \multirow{2}{*}{4246.500} & \multirow{2}{*}{-0.440} & \multirow{2}{*}{0.660} \\
\hline & 79 & 53.75 & & & & \\
\hline \multirow{2}{*}{5} & 29 & 79.33 & \multirow{2}{*}{1012.000} & \multirow{2}{*}{4172.000} & \multirow{2}{*}{-0.999} & \multirow{2}{*}{0.318} \\
\hline & 79 & 64.54 & & & & \\
\hline \multirow{2}{*}{7} & 29 & 60.53 & \multirow{2}{*}{970.500} & \multirow{2}{*}{4130.500} & \multirow{2}{*}{-1.343} & \multirow{2}{*}{0.179} \\
\hline & 79 & 52.28 & & & & \\
\hline
\end{tabular}


Table 5: Results of perceptions of auditors and users of audit report on role of audit and auditors in investor's trust

\begin{tabular}{|c|c|c|c|c|c|c|}
\hline Question & $\begin{array}{c}\text { Numbers of } \\
\text { people }\end{array}$ & $\begin{array}{l}\text { Mean } \\
\text { Rank }\end{array}$ & $\begin{array}{c}\text { Mann- } \\
\text { Whitney U }\end{array}$ & Wilcoxon W & Z & $P>\mid Z$ \\
\hline \multirow{2}{*}{13} & 29 & 50.62 & \multirow{2}{*}{1033.000} & \multirow[t]{2}{*}{1468.000} & \multirow[t]{2}{*}{-.846} & \multirow[t]{2}{*}{.398} \\
\hline & 79 & 55.92 & & & & \\
\hline \multirow{2}{*}{14} & 29 & 82.72 & \multirow{2}{*}{501.000} & \multirow[t]{2}{*}{3661.000} & \multirow{2}{*}{-4.734} & \multirow{2}{*}{.320} \\
\hline & 79 & 77.94 & & & & \\
\hline
\end{tabular}

Table 6: Results of perceptions of auditing major students and users of audit report on responsibilities of auditors for finding all errors and frauds in financial statements.

\begin{tabular}{|c|c|c|c|c|c|c|}
\hline Question & $\begin{array}{c}\text { Numbers of } \\
\text { people }\end{array}$ & Mean Rank & $\begin{array}{c}\text { Mann- } \\
\text { Whitney U }\end{array}$ & Wilcoxon W & Z & $P>\mid Z$ \\
\hline \multirow{2}{*}{1} & 57 & 29.14 & \multirow{2}{*}{1718.000} & \multirow{2}{*}{3371.000} & \multirow{2}{*}{-2.442} & \multirow{2}{*}{0.015} \\
\hline & 79 & 60.83 & & & & \\
\hline \multirow{2}{*}{2} & 57 & 27.94 & \multirow{2}{*}{2219.500} & \multirow{2}{*}{3872.500} & \multirow{2}{*}{-.150} & \multirow{2}{*}{0.000} \\
\hline & 79 & 61.14 & & & & \\
\hline \multirow{2}{*}{3} & 57 & 21.87 & \multirow{2}{*}{1303.500} & \multirow{2}{*}{2956.500} & \multirow{2}{*}{-4.300} & \multirow{2}{*}{0.000} \\
\hline & 79 & 62.45 & & & & \\
\hline \multirow{2}{*}{9} & 57 & 82.70 & \multirow{2}{*}{1442.000} & \multirow{2}{*}{4602.000} & \multirow{2}{*}{-3.757} & \multirow{2}{*}{0.000} \\
\hline & 79 & 48.31 & & & & \\
\hline
\end{tabular}

investor's trust. In the survey questionnaires collected by the group, there were 57 auditing students (accounting for $34.5 \%)$. The views of accounting and auditing students on the responsibilities of an independent auditor are clearly expressed through the following aspects: the auditor is responsible for detecting all errors and frauds on financial statements and is responsible for corporate financial scandals and the damage of users of audit information to make decisions. The authors have obtained the following results: Firstly, summarizing the opinions of auditing major student and users of audit report in detecting errors and frauds in the enterprise (see Table 6).

Table 6 showed that P-values are 0.015 and $0.000,0.000$, respectively, less than 0.05 . Thus, there are differences in the views of auditing major students and users of audit reports on the responsibilities of auditors in detecting, preventing and reporting all frauds of the units. Auditing students said that the auditor is not responsible for detecting and preventing all frauds, this responsibility belongs to the managers (see Question 9, 82.7\% of students support that statement). However, $48.31 \%$ of users of the audit report expect that the auditor will do so. Thus, Hypothesis H6 is accepted.

Secondly, summarizing the opinions of auditing major students and users of audit report on the responsibility of the auditor for corporate financial scandals and loss of the parties using the financial statements after the audit. The results are shown in Table 7. Since the value of $\mathrm{P}>|\mathrm{Z}|$ is obtained in the Table 7 of $0.751 ; 0.068 ; 0.076 ; 0.055$ are greater than 0.05 , confirming that there is no difference of opinion between the student group and the user of the audit report group. Thus, Hypothesis H7 is not accepted.

Thirdly, summarizing the opinions of students and users of audit report on role of audit and auditors in investor's trust in Table 8. The results are shown in Table 8. All questions related to the role of the auditor and auditor affect investor's trust have $\mathrm{P}>|\mathrm{Z}|$ of 0.214 and 0.081 greater than 0.05 . Therefore, there is no difference in opinion between auditing students and those using the audit report on the role of financial audit and auditors on investor's confidence. Therefore, the hypothesis H8 is not accepted.

\section{Recommendations}

The results of the study showed that there is an audit expectation gap in responsibility of auditors for the detection of all frauds, errors and protect enterprise's assets. Therefore, to reduce this kind of audit expectations gap, the authors made some recommendations as follows:

To the state management agencies: Firstly, completing the legal system and audit standards. In the process of performing the audit and giving opinions on the financial statements of the enterprise, the auditor must always 
Table 7: Perceptions results of students and users of audit report on responsibilities of auditors for corporate financial scandals and loss of the parties using the financial statements after the audit.

\begin{tabular}{|c|c|c|c|c|c|c|}
\hline Question & $\begin{array}{c}\text { Numbers of } \\
\text { people }\end{array}$ & Mean Rank & $\begin{array}{c}\text { Mann-Whitney } \\
\text { U }\end{array}$ & Wilcoxon W & $\mathbf{Z}$ & $P>|Z|$ \\
\hline \multirow{2}{*}{4} & 57 & 67.65 & \multirow{2}{*}{2184.000} & \multirow{2}{*}{5344.000} & \multirow{2}{*}{-0.317} & \multirow{2}{*}{0.751} \\
\hline & 79 & 61.63 & & & & \\
\hline \multirow{2}{*}{8} & 57 & 53.53 & \multirow{2}{*}{1856.500} & \multirow{2}{*}{3509.500} & \multirow{2}{*}{-1.827} & \multirow{2}{*}{0.068} \\
\hline & 79 & 55.75 & & & & \\
\hline \multirow{2}{*}{10} & 57 & 60.25 & \multirow{2}{*}{1834.000} & \multirow{2}{*}{3421.000} & \multirow{2}{*}{-1.921} & \multirow{2}{*}{0.076} \\
\hline & 79 & 61.31 & & & & \\
\hline \multirow{2}{*}{11} & 57 & 24.02 & \multirow{2}{*}{1115.500} & \multirow{2}{*}{2468.500} & \multirow{2}{*}{-1.005} & \multirow{2}{*}{0.055} \\
\hline & 79 & 26.57 & & & & \\
\hline
\end{tabular}

Table 8: Results of perceptions of students and users of audit report on role of audit and auditors in investor confidence

\begin{tabular}{|c|c|c|c|c|c|c|}
\hline Question & $\begin{array}{c}\text { Numbers of } \\
\text { people }\end{array}$ & Mean Rank & $\begin{array}{c}\text { Mann-Whitney } \\
\text { U }\end{array}$ & Wilcoxon W & $\mathbf{Z}$ & $P>|Z|$ \\
\hline \multirow{2}{*}{13} & 57 & 54.67 & \multirow{2}{*}{1748.000} & \multirow{2}{*}{4908.000} & \multirow{2}{*}{-2.470} & \multirow[t]{2}{*}{.214} \\
\hline & 79 & 55.92 & & & & \\
\hline \multirow{2}{*}{14} & 29 & 79.04 & \multirow{2}{*}{1021.000} & \multirow{2}{*}{4181.000} & \multirow{2}{*}{-5.792} & \multirow{2}{*}{.081} \\
\hline & 79 & 77.94 & & & & \\
\hline
\end{tabular}

comply with the laws and audit standards. The study and issuance of clear and complete audit standards will help the auditor avoid confusion in receiving information and implementing in the audit process. In Vietnam, the system of audit standards is not adequate. It is difficult for auditors and auditing companies to perform the function of verifying and expressing opinions. Therefore, it is necessary to issue a complete audit legal framework in accordance with common practice of international auditing. Therefore, a number of types of audit standards need to be issued in the future, such as: the Information Standard with those in charge of the unit; the auditor's response to the assessed risks; evaluation of identified errors in the audit; special considerations - auditing financial statements prepared for special purposes. Secondly, the Ministry of Finance and professional associations such as the Vietnam Association of Certified Public Accountants (VACPA) need to regularly check and control the quality of audit activities. There should be resolute sanctions for lowquality audits and widespread notification in the mass media so that users of financial statements know the true quality of the auditing companies. The Ministry of Finance and VACPA need to promulgate legal documents to calculate the quality of audit activities of auditing firms.

To auditors: Auditors need to comply with the requirement of independence; not being affected by the benefits when performing the audit work; independence in terms of social relations and independence in collecting and giving opinions. In addition, the auditor must have a profound knowledge of finance, accounting and auditing.

To users of audit report: It is necessary to raise the awareness of those using financial statements and audit report to help reduce the audit expectation gap. The public's knowledge needs to be improved through the media and conferences and seminars on disseminating audit knowledge, thereby communicating and explaining to users of audit services, especially financial statement audit services. It must explain the responsibilities of the auditor and the responsibilities of managers for the financial statements.

\section{Conclusion}

In recent years, there have been financial scandals in the world and in Vietnam, seriously affecting public trust in the audit profession and the role of the auditor. This study provides empirical evidence that users of audit and assurance services in Vietnam still rely on audit reports to make economic decisions. This proves that the financial audit plays an important role in the Vietnamese economy, demonstrating independent supervision from outside the firm performance. With the results obtained through this survey, it can be seen that the society often puts more expectation on the auditor's responsibilities in detecting all errors and frauds of audited firms, while there is not much difference in opinion between users of audit in the role of audit and auditors in keeping assurance and trust of investors. 


\section{References}

Best, P., Buckby, S., \& Tan, C. (2001). Evidence of the audit expectation gap in Singapore. Managerial Auditing Journal, 16(3), 134-144.

Baron, C. D, Douglas, A., Johnson, A., Searfoss, G. \& Smith, H. (1977). Uncovering corporate irregularities: are we closing the expectation gap? Journal of Accountancy, 144(3), 243-250.

Chu, J., \& Ki, S. E. (2019). Do auditor's efforts of interim review curb the analyst forecast's walkdown? Journal of Asian Finance, Economics and Business, 6(2), 45-54. https:// doi.org/10.13106/jafeb.2019.vol6.no2.45

CEpstein, M. J., \& Geiger, M.A. (1994). Investor views of audit assurance: recent evidence of the expectation gap. Journal of Accountancy, 60-66.

Fadzly, M. N., \& Ahmad, Z. (2004). Audit expectation gap: the case of Malaysia. Managerial Auditing Journal, 19(7), 897-915.

Guy, D., \& Sullivan, J. (1988). The expectation gap auditing standards. Journal of Accountancy, 165(4), 36-46.

Humphrey, C., Moizer, P., \& Turley, S. (1993). The audit expectations gap in Britain: an empirical investigation. Accounting and Business Research, 23(91A), 395-411.

Jensen, M. C., \& Meckling, W. (1976). Theory of the firm: managerial behavior, agency costs and ownership structure. Journal of Financial Economics, 3, 305-360.

Liggio, C. D. (1974). The Expectation Gap: The Accountant's Waterloo. Journal of Contemporary Business, 3(3), 27-44.

Lin, Z., \& Chen, J. (2004). Auditors responsibility and independence: evidence from China. Research in Accounting Regulation, 17(1), 93-115.

Low, A.M. (1980). The auditor's detection responsibility: is there an expectation gap? Journal of Accountancy, 150(1), 65-70.

Low, A. M., Foo. S., \& Koh. H. (1988). The expectation gap between financial analysts and auditors - some empirical evidence. Singapore Accountant, 4(2), 10-13.

Lee, T. A. (1970). The nature of auditing and its objectives. Accountancy, 81(1), 32-34.

Monroe, G. S., \& Woodliff, D. R. (1993). The effect of education on the audit expectation gap. Accounting and Finance, 33(1), $61-78$.
McEnroe, J. E., \& Martens, S. C. (2001). Auditors and investors' perceptions of the expectation gap. Accounting Horizons, 15 (4), 345-358.

Nguyen, A. H., \& Duong, C. T. (2020). Provincial governance quality and earnings management: empirical evidence from Vietnam. Journal of Asian Finance, Economics and Business, 7(2), 43-52. https://doi.org/10.13106/jafeb.2020.vol7.no2.43

Nguyen, A. H., Pham, H. T., \& Nguyen, H. T. (2020). Impact of working capital management on firm's profitability: empirical evidence from Vietnam. Journal of Asian Finance, Economics and Business, 7(3), 115-125. https://doi.org/10.13106/ jafeb.2020.vol7.no3.115

Nguyen, H. P. T., \& Tran, M. H. L. (2017). The determinants of audit fees for companies in Vietnam. Journal of Economics and Development, 19(2), 68-88.

Pham, L.T., \& Hoang, H. V. (2019). The relationship between organizational learning capability and business performance: the case of Vietnam firms. Journal of Economics and Development, 21(2), 259-269.

Rahman, M. M., Meah, R. M., \& Chaudhory, U. N. (2019). The impact of audit characteristics on firm performance: an empirical study from an emerging economy. Journal of Asian Finance, Economics and Business, 6(1), 59-69. http:// doi.org/10.13106/jafeb.2019.vol6.no1.59

Salehi, M., \& Azary, Z. (2008). Fraud detection and audit expectation gap: Empirical evidence from Iranian bankers. International Journal of Business and Management, 3(10), 65-73.

Tran, M. D., Khairi, K. F., \& Laili, N. H. (2019). A longitudinal study of audit quality differences among independent auditors. Journal of Economics and Development, 21(2), 234-246.

Tran, Q. T. (2019). Independent directors and corporate investment: evidence from an emerging market. Journal of Economics and Development, 21(1), 30-41.

Vinten, G. (2005). Audit expectation - performance gap in the United Kingdom in 1999 and comparison with the gap in New Zealand in 1989 and in 1999. Managerial Auditing Journal, 20(5), 561-562.

Yasemin, K., \& Sedat. E. (2015). The audit expectations gap in Turkey. The Journal of Accounting and Finance, 193-211. 